\title{
X-linked intellectual disability, Wilson type
}

INSERM

\section{Source}

INSERM. (1999). Orphanet: an online rare disease and orphan drug data base. $\underline{X \text {-linked }}$ intellectual disability, Wilson type. ORPHA:85290

X-linked intellectual disability, Wilson type is characterised by severe intellectual deficit with mutism, epilepsy, growth retardation and recurrent infections. It has been described in three males from three generations of one family. The causative gene has been localised to the $11 \mathrm{p}$ region of the $\mathrm{X}$ chromosome. 